\title{
Bilateral radial nerve palsy in a newborn
}
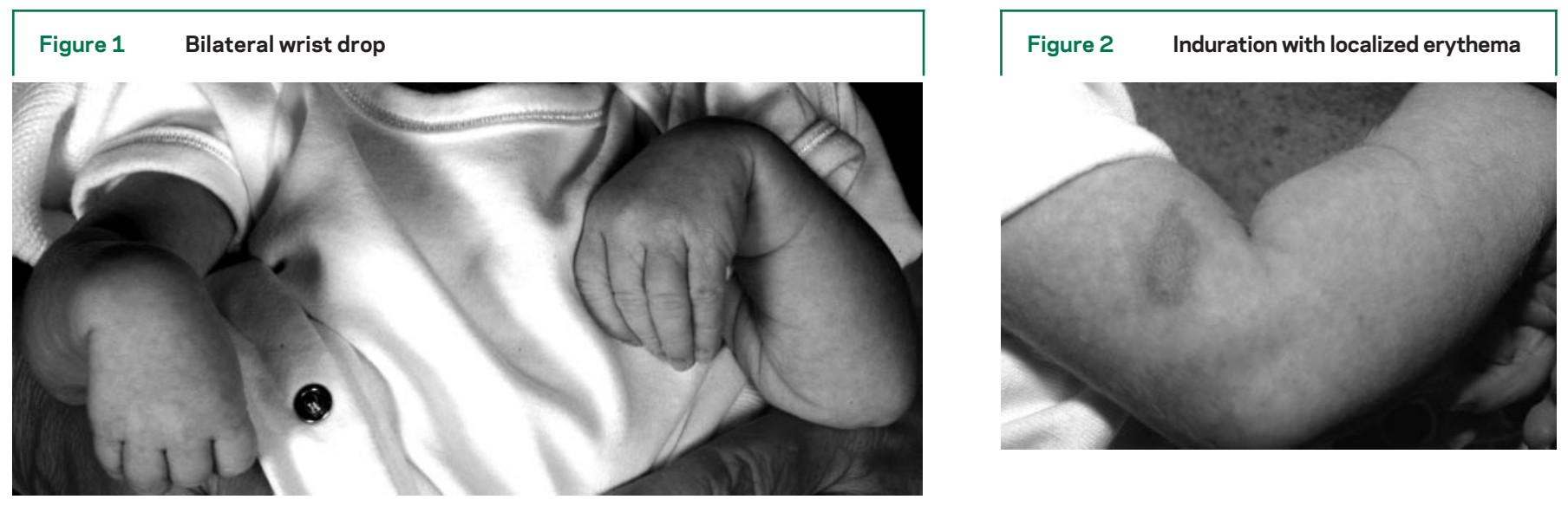

A boy was born at 42 weeks' gestation following 4 days of labor. Epidural anesthesia was used. Bilateral wrist drop was noted immediately after delivery (figure 1). Induration with localized erythema was seen symmetrically on the dorsal aspect of both upper limbs (figure 2). Examination was in keeping with isolated bilateral radial nerve palsies.

An ultrasound scan of the upper arms revealed symmetric thickening of the radial nerves distal to the radial groove at the posterolateral humerus. Electrophysiology tests suggested no evidence of acute denervation. Following physiotherapy and occupational therapy, improvement in the infant's wrist position was seen within 2 weeks of birth. Postulated mechanisms for these injuries include reduced fetal activity for reasons including reduced amniotic fluid volume. ${ }^{1,2}$

Claire T. Lundy, MRCPCH, Sushma Goyal, MRCPCH, Silke Lee, FRCPCH, Tammy Hedderly, MRCPCH, London, UK

Disclosure: The authors report no disclosures.

Address correspondence and reprint requests to Dr. Claire Lundy, Department of Paediatric Neurology, Evelina Children's Hospital, St Thomas' Hospital, Lambeth Palace road, London, SE1 7EH, UK; clairelundy@btopenworld.com

1. Hayman M, Roland EH, Hill A. Newborn radial nerve palsy: report of four cases and review of published reports. Pediatr Neurol 1999;21:648-651.

2. Richardson GA, Humphrey MS. Congenital compression of the radial nerve. J Hand Surg [Am] 1989;14:901-903. 


\section{Neurology}

\section{Bilateral radial nerve palsy in a newborn}

Claire T. Lundy, Sushma Goyal, Silke Lee, et al. Neurology 2009;72;576

DOI 10.1212/01.wnl.0000342126.70570.33

\section{This information is current as of February 9, 2009}

\section{Updated Information \& Services}

\section{References}

\section{Subspecialty Collections}

Permissions \& Licensing

Reprints including high resolution figures, can be found at: http://n.neurology.org/content/72/6/576.full

This article cites 2 articles, 0 of which you can access for free at: http://n.neurology.org/content/72/6/576.full\#ref-list-1

This article, along with others on similar topics, appears in the following collection(s):

All clinical neurophysiology

http://n.neurology.org/cgi/collection/all_clinical_neurophysiology All Pediatric

http://n.neurology.org/cgi/collection/all_pediatric

\section{All Rehabilitation}

http://n.neurology.org/cgi/collection/all_rehabilitation

Neonatal

http://n.neurology.org/cgi/collection/neonatal

Ultrasound

http://n.neurology.org/cgi/collection/ultrasound

Information about reproducing this article in parts (figures,tables) or in its entirety can be found online at:

http://www.neurology.org/about/about_the_journal\#permissions

Information about ordering reprints can be found online: http://n.neurology.org/subscribers/advertise

Neurology ${ }^{\circledR}$ is the official journal of the American Academy of Neurology. Published continuously since 1951, it is now a weekly with 48 issues per year. Copyright . All rights reserved. Print ISSN: 0028-3878. Online ISSN: 1526-632X.

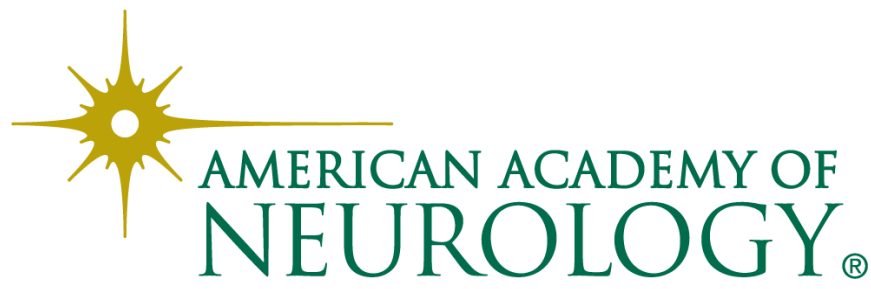

